\title{
Enzyme Secretion Alteration
}

National Cancer Institute

\section{Source}

National Cancer Institute. Enzyme Secretion Alteration. NCI Thesaurus. Code C41549.

A finding indicating a deficiency or excess in secretion of one or more enzymes. 